\title{
ОБРЯДОВЫЕ УКЛОНЕНИЯ И ДУРНЫЕ ПРИВЫЧКИ ЛАТИНСКИХ ЕРЕТИКОВ В ВИЗАНТИЙСКО-СЛАВЯНСКОЙ ПОЛЕМИЧЕСКОЙ ЛИТЕРАТУРЕ СРЕДНЕВЕКОВЬЯ
}

Тема о догматических и обрядовых различиях между восточными (православными) и западными (латинскими) христианами в средневековой эпохе весьма широка и едва ли поддается исчерпывающему анализу в рамках короткого доклада. Исходя из этого соображения, мы посвятим наше выступление только двум из многочисленных аспектов этой проблематики, а именно - вопросам о брадобритии и об использовании мяса нечистых животных. Исходным пунктом наших наблюдений в обоих случаях станут перечни обрядовых уклонений и дурных привычек латинских еретиков, которые распространялись в Византии со второй половины XI в., а их переводы и переработки были весьма популярны среди православных славян на Балканах и в Восточной Европе по крайней мере до конца XVII в.

В отличие от богословских трактатов, которые интерпретировали различия между церквами в плоскости Священного Писания, святоотеческой традиции и церковных канонов, византийско-славянские списки прегрешений латинян содержали лишь сжатое перечисление соответствующих уклонений и ошибок западных христиан в форме, которая принимала за данность, что отвратительная природа этих верований и практик является самоочевидной․․ Как отмечал А. Павлов, при этом само собою предпотагалось, что все, несогтасное с обычаями и уставами православной церкви, есть заблуждение, ересь, и что чем больше таких несогтасий, тем гнуснее и погибельнее выражающееся в них еретичество 2 .

Основоположником этого специфического жанра стал константинопольский патриарх Михаил Кируларий: в его письме антиохийскому патриарху Петру II (III), составленном по поводу церковного разрыва между Римом и Константинополем в 1054 г., впервые был помещен список ошибок латинян вышеупомянутого типа ${ }^{3}$. Изложенные в этом перечне разнообраз-

\footnotetext{
${ }^{1}$ T. Kolbaba, Meletios Homologetes On the Customs of the Italians, REB 55, 1997, p. 140.

2 А. ПАвлов, Критические опыты по истории древнейшей греко-русской полемики против латинян, Санкт-Петербург 1878, p. 44.

${ }^{3}$ T. Kolbaba, The Byzantine Lists. Errors of the Latins, Urbana-Chicago 2000, p. 23-26; L. Sels,
} 
ные обвинения - о применении бесквасного хлеба в евхаристии, употребления удавленины, свиного сала и скверной пищи, брадобритии, соблюдении субботнего поста, filioque, безбрачии священников и т.д. - вошли в устойчивый репертуар более поздних византийских полемистов, чьи списки ересей латинских часто переводились на славянский язык; рукописная традиция этих переводов относительно хорошо прослеживается по крайней мере со второй половины XIV в. (к этому времени относятся древнейшие уцелевшие сборники, в которых содержатся тексты интересующего нас типа) $)^{4}$.

Характерной особенностью эволюции списков прегрешений латинян как в Византии, так и у славян, является тенденция к варьированию и дальнейшему обогащению отдельных (преимущественно бытовых) обвинений новыми, подчас весьма диковинными, отталкивающими или просто нелепыми деталями, которые более подходили бы апокрифическим, нежели полемическим текстам. Здесь мы ограничимся только двумя примерами, которые хорошо иллюстрируют, с одной стороны, популярность стандартных перечней латинских ересей в православной среде, а с другой - склонность анонимных славянских переписчиков и грамотеев творчески развивать традиционные мотивы антилатинской полемики.

Первый пример связан с уже упомянутым лаконичным обвинением Михаила Кирулария латинянам, что они бреются 5 . В своем ответном письме антиохийский патриарх Петр отбросил это обвинение ввиду его бытовой незначительности ${ }^{6}$. Учитывая это, нельзя удивиться, что на протяжении следующих десятилетий далеко не все византийские полемисты придавали особое значение традиции западного духовенства бриться, поскольку о ней не упоминается ни в Повести полезной о татинах (переведенной с утраченного греческого оригинала на славянский язык около начала XII в.), ни

Lawless, Forbidden and Abominable Customs: О Латинихъ сирrъчь Фроугохъ, a Slavonic list of Latin errors, [in:] (Mis)Understanding the Balkans. Essays in Honour of Raymond Detrez, ed. M. DE DoBBeLEer, S. Vervaet, Gent 2013, p. 272-273.

${ }^{4}$ А. ПоПов, Историко-литературный обзор древнерусских полемических сочинений против латинян (XI-XV в.), Москва 1875; А. ПАвлОв, ор. cit., passim; М. ЧЕЛЬцОв, Полемика между греками и татинянами по вопросу об опресноках в XI-XII вв., Санкт-Петербург 1879; A. Nixolov, Mediaeval Slavonic Anti-Catholic Texts from the Manuscript Collection of the Romanian Academy, [in:] New Europe College Regional Program 2003-2004, 2004-2005, Bucharest 2007, p. 261-290; IDEM, Место и роль Болгарии в среденевековой полемике православного Востока против католического Запада (на основе славянских переводных и оригинальных текстов XIXIV в8.), [in:] XVIII Ежегодная богословская конференция Православного Свято-Тихоновского гуманитарного университета, vol. I, Москва 2008, p. 123-127.

${ }^{5} P G$, vol. 120, col. 789. Cf. А. Попов, op. cit., p. 48, 52.

${ }^{6} P G$, vol. 120 , col. 800 . 
в созданной после середины ХІ в. псевдо-Фотиевой статье $О$ франках и прочих латинах, славянский перевод которой в первой половине XIII в. попал в Сербскую кормчую, а списки этого произведения часто присутствуют и в дошедших до нас полемических сборниках XIV-XVII вв.

C разгоранием конфликтов между Востоком и Западом и особенно после захвата Константинополя в 1204 г. войсками Четвертого крестового похода, ношение бороды с точки зрения византийцев окончательно стало устойчивым внешним признаком их этнической идентификации, а вместе с тем обрело и определенное религиозное значение ${ }^{8}$.

Эта тенденция нашла отголосок также среди болгар и сербов, ближайших соседей империи на Балканах. Прямым свидетельством тому является помещенная в Сербской кормчей (употребляемой в XIII-XIV в. и Болгарской церковью) полемического произведения против латинян известного византийского богослова XI в. Никиты Стифата, в котором имелся специальный параграф, осуждающий брадобритие священников 9 . Учитывая это, не стоит удивляться, что в опубликованной А. Павловым интерполированной славянской версии перечня обвинений Михаила Кирулария подчеркивается, что латиняне не принимают причащение от небритых священников (а это имплицитно подсказывает о подобном отношении православных к бритым священнослужителям): Священники их стригут бороду и оставляют своих жен. А ежели не бреют, миряне не принимают причащаться у них $x^{10}$.

Брадобритие западного духовенства заняло важное место среди 72 ере-

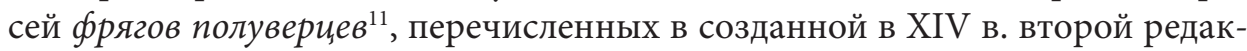
ции славянского перевода Прения Панагиота с Азимитом, чья первоначальная греческая версия возникла вскоре после заключения в 1274 г. Лионской унии с Римской церковью императором Михаилом VIII Палеологом.

В ходе своего диалога с Азимитом в присутствии императора, его свиты и римских кардиналов, ревнитель православия Панагиот спросил у своего оппонента, почему папа стрижет свою бороду. Азимит объяснил, что в ноч-

\footnotetext{
${ }^{7}$ А. ПоПов, ор. cit., p. 57-58, 134; А. ПАвЛов, ор. cit., p. 70; И. Чичуров, Схизма 1054 г. и антилатинская полемика в Киеве (сер. XI - нач. ХII в.), RM 9.1, 1997, p. 43-53; IDEм, Ein antilateinischer Traktat des Kiever Metropoliten Ephraim, [in:] Fontes Minores, vol. X, Frankfurt am Mein 1998, p. 319-356; IDEм, Антилатинский трактат киевского митрополита Ефрема (ок. 1054/55 - 1061/62 г2.) в составе греческого канонического сборника Vat. Gr. 828, ВПСТГУ 3.1 (19), 2007, p. 107-132; L. SELS, op. cit., p. 274. Текст полемической псевдо-Фотиевой статьи был воспроизведен в Истории вкратце о болгарском народе словенском, составленной в 1792 г. иеромонахом Спиридоном Габровским (1740-1824), близким учеником и соратником известного игумена Нямецкого монастыря Паисия Величковского (1722-1794). СВ. ЙЕРОсХИМОНАХ СПиРИдОН, История вкратие о болгарском народе словенском, еd. В. ЗЛАТАРСКИ, София 1900, p. 59-61.

${ }^{8}$ T. Kolbaba, The Byzantine Lists..., p. 57.

${ }^{9}$ А. Попов, op. cit., p. 131-132.

${ }^{10}$ А. ПАВЛОВ, op. cit., p. 152.

${ }^{11}$ А. Попов, op. cit., p. 274, 276.
} 
ном видении папа получил распоряжение побриться и уподобиться таким образом ангелу, поскольку ангелы безбородыми предстоят престолу Божию. В ответ Панагиот обвинил его во лжи и рассказал совсем другую историю: папе захотелось иметь женщину, но его избранница обещала прийти к нему только если он побреется. Он так и поступил, и послал ей свою бороду, но

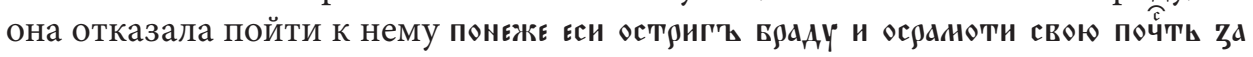
нои жєнскїи пол'ъ ${ }^{12}$. Тогда папа созвал епископов и священников и убедил их тоже сбрить свои бороды, дабы удостоились ангельского чина ${ }^{13}$.

B XV в. анонимный сербский или болгарский автор положил этот сюжет в основу нового полемического произведения под заглавием Сказание как Рим отпал от православной веры. Составитель этого текста постарался превратить коротко переданный в Прении Панагиота и Азимита анекдот в настоящую сказочную историю, обогатив ее рядом деталей, характерных для устной народной традиции:

И [папа] послал письмо на дворы девичьи, в котором писал: Папа тебе кланяется, приходи в апостольский престол вечером ужинать с папой. А девица эта была богомудрая, Святым Духом исполненная. Когда пришло письмо, она его бросила в огонь; и второе, и третье, и четвертое, и пятое, и шестое. Седьмое было гневным. В седьмом письме было написано: Девушка, ты не можешь убежать от рук папь! А девушка посоветовалась с Святым Духом и послала папе письмо, отвечая: Святой папа, пришли мне свои золотые волосы, и бороду, и усы, если хочешь меня любить. Ведь я от лучшего колена, колена Израилева. И почему девушка написала письмо? Чтобы папа отстал от девушки. А говорила себе девушка: Если папа сбреет бороду и усы из-за женщины, земля провалится [и] небеса раздерутся; и папа этого не cделает. И папа, прочитав письмо девушки и призвав одного настоящего умельца-цирюльника, сбрил свою бороду и усы. И послал золотую бороду и усы девушке. Девушка увидела золотую бороду и усы и сильно заплакала, отрезала свои светлые волосы и ударила головой о камни. ${ }^{14}$

Следует отметить, что в 1640 г. это произведение вызвало возмущение католического епископа Галлиполи Петра Богдана Бакшева (1601-1674), будущего архиепископа Софии. В докладе о своей поездке по землям бывшего королевства Болгарии, отправленном Конгрегации по распространению веры, он отмечал:

Святой Церкви известна схизма как греков, так и болгар и других народов; но у болгар она, не знаю почему, сильнее по сравнению с остальными, поскольку они, будучи людьми про-

\footnotetext{
${ }^{12}$ Ibidem, p. 273-274.

${ }^{13}$ Ibidem, p. 274.

${ }^{14}$ Издание приведенного текста и сведения о трех сохранившихся его списках: А. Николов, „Сказание как Рим отпадна от православната вяра" - една непозната късносредновековна инвектива срещу Папството, [in:] Тангра. Сборник в чест на 70-годишнината на акад. Васил Гюзелев, ed. М. КАЙМАКАМОВА et AL., София 2006, p. 193-201. Сf. также: А. НИКОЛОв, К истории средневековой южнославянской полемики против Папства: „Сказание, как Рим отпал от православной веры", [in:] Русское богословие: традииия и современность. Сборник статьей, ed. П. Хондзинский, Н.Ю. СуховА, Москва 2011, р. 123-132.
} 
стыми и невежественными, верят всему написанному, что обрется. Я даже нашел одну ихнюю книгу и извлек много безумств, которых они поддерживают и которые являются чистой ересью... Когда разговариваешь с ними о вещах, связанных с верой и церковью, они говорят: У папы была золотая борода и он ее сбрил из-за любви к одной римлянке. И от стыда он не смог приехать на Седьмой собор, но, оставшись в Риме, разделил веру - бессмыслицы, которые невероятны. ${ }^{15}$

Доклад Петра Богдана подсказывает, что мы не должны судить об общественной значимости исследуемых нами средневековых текстов, основываясь только на сухие данные о количестве уцелевших списков. В данном случае Сказание как Рим отпал от православной веры достигло до нас в двух полных и одной неполной копиях, но доступные сведения о широкой популярности произведения около середины XVII в. подсказывают, что списки, которые ходили по рукам в этот период, были весьма многочисленны.

$$
* * *
$$

Второй пример, на котором мы остановим свое внимание, связан с одним из наиболее частых обвинений против католиков, что они едят мясо диких и нечистых животных. В послании Михаила Кирулария Петру Антиохийскому этот мотив только обозначен, но константинопольский патриарх не счел необходимым входить в подробности кроме того, что латиняне употребляют удавленину и нечистое мясо (

Этот пункт был оспорен Петром Антиохийским на основе новозаветного рассказа о видении, явленном апостолу Петру перед его встречей с сотником Корнилием:

На другой день, когда они шли и приближались к городу, Петр около шестого часа взошел на верх дома помолиться. И почувствовал он голод, и хотел есть. Между тем, как приготовляли, он пришел в исступление и видит отверстое небо и сходящий к нему некоторый сосуд, как бы большое полотно, привязанное за четыре угла и опускаемое на землю; в нем находились всякие четвероногие земные, звери, пресмыкающиеся и птицы небесные. И был глас к нему: встань, Петр, заколи и ешъ. Но Петр сказал: нет, Господи, я никогда не ел ничего скверного или нечистого. Тогда в другой раз [был] глас к нему: что Бог очистил, того ты не почитай нечистым (Деян. 10, 10-15).

Как отмечает Б. Кростини, Петр Антиохийский привлек этот новозаветный пассаж неслучайно, поскольку он обессилил ветхозаветное разграничение между чистыми и нечистыми животными, проведенное в Лев. 11

\footnotetext{
${ }^{15}$ E. FermendžIn, Acta Bulgariae ecclesiastica ab a. 1565 ad a. 1799, Zagrabiae 1887 [= MSHSM, 18], p. 69-70.

${ }^{16}$ А. Попов, op. cit., p. 48.
} 
и Втор. 14, и, тем самым, стал основой святоотеческого учения о пище ${ }^{17}$.

Наряду со ссылками на авторитет Писания, Петр указал Михаилу Кируларию и на то, что под удары его суровой критики вполне могут попасть и некоторые из наших, а именно: вифинцы, фракийцы и лидиицы едят галок, ворон, горлии, и дикобразов ${ }^{18}$.

Изложенные антиохийским патриархом доводы, направленные по существу против тревожной тенденции стирания границ между привычками питания и литургической сферой ${ }^{19}$, не помешали некоторым более поздним византийским полемистам приписать латинянам употребление разнообразных нечистых животных и тварей: медведей, шакалов, бобров, черепах, лягушек, мышей, ворон, бакланов и др. ${ }^{20}$

Тенденция к постоянному обогащению этих списков прослеживается и в славянских версиях антилатинских текстов.

В расширенной славянской редакции послания Кирулария, опубликованной А. Поповым, под № 20 помещено обвинение, в котором утверждает-

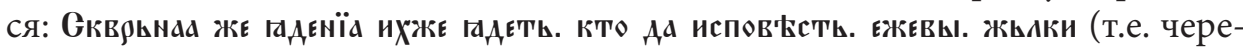

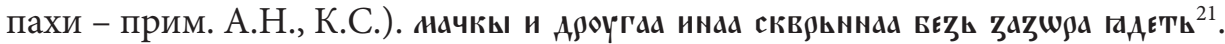

В псевдо-Фотиевой статье О франках и прочих латинах этому вопросу посвящен пункт № 12, который в средневековом славянском переводе зву-

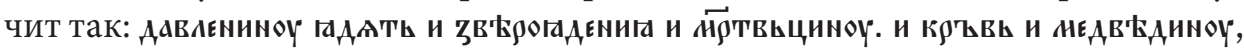

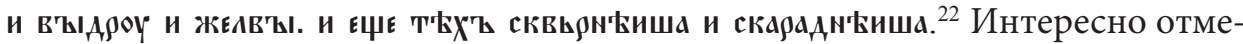
тить, что перевод модифицирует греческий оригинал, в котором на месте

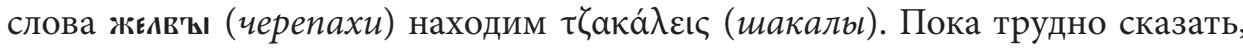
однако, является ли это целенаправленным изменением текста переводчиком, или последнему просто попался греческий текст, в котором имелось такое разночтение.

В уже упомянутой интерполированной версии списка Кирулария пункт № 29 содержит другое перечисление нечистых животных: Ifдоүты жє вслкоү

\footnotetext{
${ }^{17}$ B. Crostini, What was kosher in Byzantium?, [in:] Eat, Drink, and Be Merry (Luke 12:19) - Food and Wine in Byzantium. Papers Delivered at the 37th Annual Spring Symposium of Byzantine Studies under the Auspices of the Society for the Promotion of Byzantine Studies, in Honour of Professor A.A.M. Bryer, at the University of Birmingham, 29-31 March 2003, ed. L. BrubaKer, K. LinARdou, Aldershot 2007, p. 166-167.

${ }^{18} P G$, vol. 120 , col. 800-801.

${ }^{19}$ B. Crostini, op. cit., p. 171.

20 T. KolвAвA, The Byzantine Lists..., p. 35-36 (обзор сведений). Здесь уместно привести замечания Д. ШЕФЕЛЯ, которые валидны и что касаются распространения традиционных византийских концепций о нечистой пище среди южных славян: It was the Greek folk system of dietary purity which penetrated Kievan and later Muscovite Rus'. As in Byzantium, the Muscovite distinction between pure and impure food reflected the Mosaic laws and the Latins were held in contempt for their postulated proclivity for sharing meals with dogs, drinking blood, and eating the meat of defiled animals (D. Scheffel, In the Shadow of Antichrist. The Old Believers of Alberta, Peterborough 1991, p. 194).

${ }^{21}$ А. Попов, op. cit., p. 54.

${ }^{22}$ Ibidem, p. 62.
} 


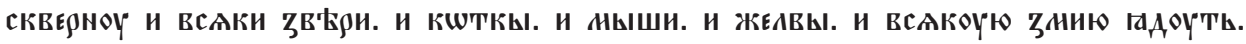
и жаБоу заПаднии Аатине. ${ }^{23}$

Как отмечал А. Павлов ${ }^{24}$, очень схожее, но еще более развернутое описание нечистой пищи католиков фигурирует в Повести полезной о латинах:

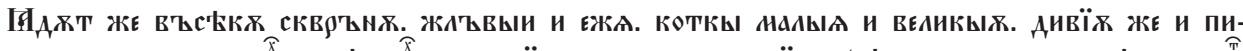

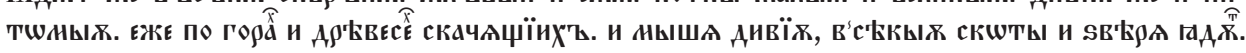

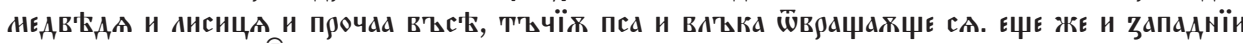

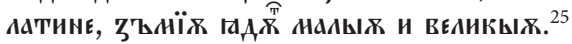

Это цветистое описание отвратительных привычек латинян настолько понравилось анонимному сербскому переписчику конца XIV в., связанному с сербской патриаршеской канцелярией, что после упоминания о малых и великих змеях он добавил от себя еще одну деталь: и г४щєяє и г४щєрицє (и ямеров и ямерии) $)^{26}$.

Интересно также сопоставить варьирование перечней животных, помещенных в разных версиях Прения Панагиота с Азимитом (учитывая при этом и разницы между опубликованными греческими списками $)^{27}$. В первой редакции (согласно классификации А. Попова) список гласит так: поч'то

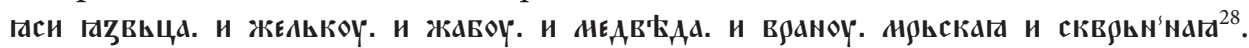
В русском списке XVI в., по которому А. Попов опубликовал текст второй ре-

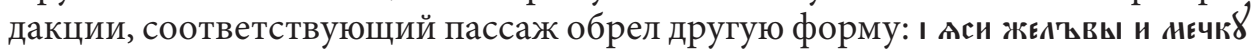

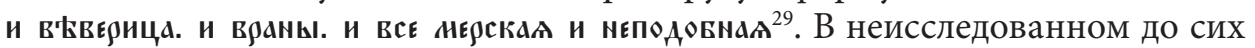

\footnotetext{
${ }^{23}$ А. ПАВЛОВ, op. cit., p. 154-155.

${ }^{24}$ Ibidem, p. 79. Автор в осторожной форме высказал весьма убедительное предположение, что перечень латинских прегрешений, помещенный в Повести полезной о латинах служил источником для составителя интерполированной версии обвинительного списка Михаила Кирулария.

25 А. Николов, Повест полезна за латините: паметник на средновековната славянска полемика срещу католицизма, София 2011, p. 77. Старое издание: А. ПоПов, ор. cit., p. 184-185 ${ }^{26}$ А. Николов, Повест полезна за латините..., р. 77 (прим. 296), 123 (прим. 50). Как установила Л. Цернич, этот анонимный переписчик Повести полезной о латинах, который списал тексты на лл. 28об. - 54 рукописи Рс 11 Народной библиотеки Сербии, изготовил в 1380 и 1388 г. две грамоты сербского патриарха Спиридона (1380-1389), которые ныне хранятся в библиотеке Хиландарского монастыря (Л. ЦЕРНић, О атрибуцији средюовековних српских ћирилских рукописа, [in:] Међународни научни скуп „Текстологија средюовековних јужнословенских књижевности" 14-16. новембра 1977, Београд 1981 [= САНУ.НС.ОЈК, 10,2], p. 356-357, кат. № 74-76, сл. 70-71).

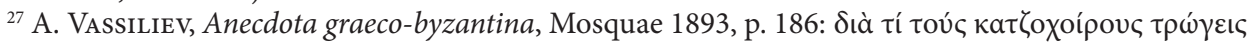

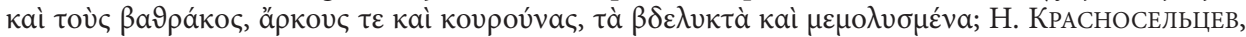
„Прение Панагиота с Азимитом" по новым греческим спискам, ЛИФО.ВО 6.3, 1896, р. 321-

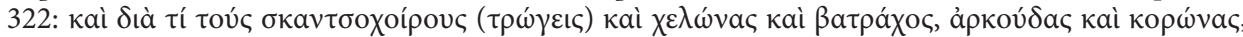
$\tau \grave{\alpha} ı \beta^{\prime} \beta \delta \varepsilon \lambda v_{\gamma} \mu \alpha \tau \alpha \mu \varepsilon \mu \nu \lambda v \sigma \mu \varepsilon ́ v \alpha$.

${ }^{28}$ А. Попов, op. cit., p. 260.

${ }^{29}$ Ibidem, p. 275. В молдавском списке болгарского правописания, конца XVI в. (1580/1590),

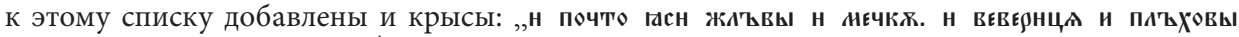

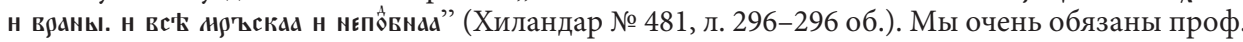
П. Матейичу и Хиландарской исследовательской библиотеке Государственного университета
} 
пор сербском списке Прения 30-ых годов XV в. перечень гласит: почто гастє

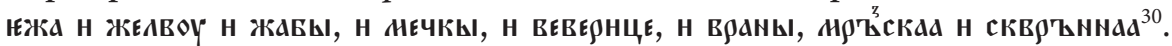

Примеры подобных перечислений животных и яств можно множить ${ }^{31}$, но это не входит в цели нашего изложения. Для нас важно отметить, что генезис этих перечней пока остается неясным для исследователей ${ }^{32}$. Все-таки, есть основания предположить, что авторы списков латинских вин пользовались материалом, почерпнутым из византийских епитимийных сборников типа т.наз. Номоканона Котелерия, где (вне всякой полемической линии против латинян или других еретиков) помещен параграф, устанавливающий покаяние на два года и сто поклонов в день за употребление мяса нечистых животных (преимущественно птиц) - орла, сокола, сыча, ворона, ястреба, куницы, сороки, кукушки, петуха, ласточки, черепахи, аиста, мыши, морского ежа или пеликана ${ }^{33}$.

Славянская версия этого сборника, обозначаемая в научной литературе названиями Номоканон Псевдо-Зонары или просто Зинар, хорошо засвидетельствована в болгарской, сербской и русской рукописных традициях ${ }^{34}$.

Огайо (США) за любезно предоставленные нам копии полемических текстов, помещенных в рукописях № 481 и № 469 собрания Хиландарского монастыря.

${ }^{30}$ Хиландар № 469, л. 304.

${ }^{31}$ Об антилатинской полемике на Руси v. работы И.С. Чичурова, указанные выше в прим. 7, а также: Г. ПодсКАЛЬсКИ, Христианство и богословская литература в Киевской Руси (9881237 z2.), trans. А.В. НАЗАРЕНКО, еd. К.К. АКЕНТьЕВ, ${ }^{2}$ Санкт-Петербург 1996, p. 280-303; А. БАРмИН, Полемика и схизма. История греко-латинских споров IX-ХII вв. Москва 2006; Г. БАРАНковА, Антилатинские Послания митрополита Никифора: лингвистический и текстологический аспекты исследования, [in:] Лингвистическое источниковедение и история русского языка (2002-2003), Москва 2003, р. 317-359; ЕАDЕм, „Стязание с татиною” киевского митрополита Георгия, [in:] Лингвистическое источниковедение и история русского языка (2004-2005), Москва 2006, р. 29-58; ЕАDЕм, Текстологические и языковые особенности антилатинского апокрифического памятника "Сказание о двенадиати апостолах, о татине и о опресноцех", ВПСТГУ.БФ 3 (27), 2009, р. 67-92; ЕАDЕм, Антилатинские полемические сочинения в Киевской Руси XI-XIII вв., [in:] Русское богословие..., p. 105-122.

${ }^{32}$ К примеру, пока не исследован вопрос о возможных взаимовлияниях между списками латинских прегрешений и описаниями отталкивающих питательных привычек нечистых народов, запертых Александром Македонским за горами на крайнем севере ойкумены, в разнообразных греческих и славянских версиях Откровения Мефодия Патарского - cf. В. Истрин, Откровение Мефодия Патарского и апокрифические видения Даниила в византийской и славяно-русской литературах. Исследование и тексты, Москва 1897, p. 18 (комары, мухи, кошки, змеи), 63 (змеи и скорпионы), 89 (комары, мыши, кошки, змеи), 106 (комары, мухи, змеи), 125 (комары, мыши, кошки, змеи); Die Apokalypse des Ps.-Methodios, ed. A. Lolos, Meisenheim am Glan 1976, p. 78 (собаки, мыши, кошки, змеи), 79 (комары, мыши, змеи); F. Тномson, The Slavonic Translations of Pseudo-Methodius of Olympи Apocalypsis, [in:] Търновска книжовна школа, vol. IV, Културно развитие на българската държава краят на XII-XIV век. Четвърти международен симпозиум Велико Търново, 16-18 октомври 1985 г., ed. А. ДАвидов et al., София 1985, p. 60 (комары, мухи, кошки, змеи); Die Apokalypse des Pseudo-Methodius. Die älteste griechischen und lateinischen Übersetzungen, Hrsg. W. Aerts, G. KortekaAs, vol. I, Einleitung, Texte, Indices Locorum et Nominum, Lovanii 1998 [= CSCO.S, 569/597], p. 108 (собаки, мыши, кошки, змеи) ${ }^{33}$ J.-B. Cotelerius, Ecclesiae Graecae monumenta, Luteciae-Parisiorum 1677, p. 127 (№ 317).

${ }^{34}$ М. ЦИБРАНСКА-КосТОвА, Славянският Псевдозонар, Pbg 32.4, 2008, p. 25-52; Д. НАЙДЕНОвА, Каноничноправни текстове в състава на славянски рбкописи, съхранявани в български 
Следует отметить, что древнейший уцелевший список этого произведения (ГИМ, Хлуд. 76) был создан в 30-ые годы XIV в. тем же писцом, которому принадлежит и основная часть Синодальной копии Хроники Константина Манассии, иными словами - речь идет о рукописи, которая была создана в болгарской столице Тырново и (вероятно) принадлежала скрипторию царя Ивана Александра (1331-1371) 35 .

Перечисления нечистых животных в сборниках этого типа включены в статью, которая обычно носит заглавие О мрьцинахъ. Здесь воспроизводим соответствующий пассаж в переводе по фототипически опубликованному болгарскому списку 1360-ых годов XIV в., помещенному в рукописи № 1160 из собрания Церковно-исторического и архивного института Болгарского патриархата в Софии (ЦИАИ 1160), с указанием некоторых разночтений по спискам из болгарских собраний - № 1/20 Национального музея Рильский монастырь (НMPM 1/20), XVI в.; № 6 (2617) Регионального исторического музея в г. Шумен (РИМШ 6), сер. XVI в.; № 101 (36) Народной библиотеки им. Ивана Вазова в г. Пловдив (НБИВ 101), вт. пол. XVI - пер. пол. XVII в.:

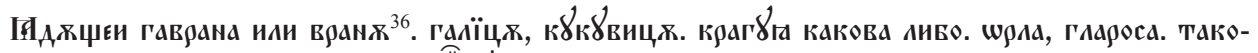

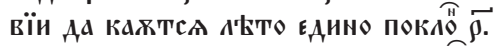

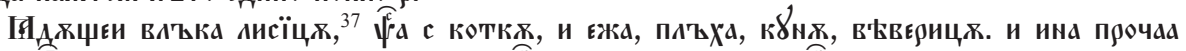
Елика с⿱乛龰

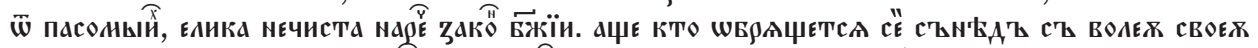

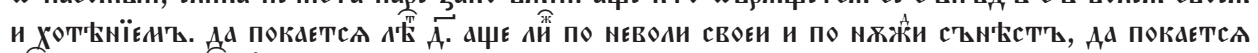

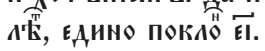

Те, кто едят ворона или воронуз ${ }^{39}$ сороку, кукушку, какого-либо сокола, орла, чайку: пусть такие каются один год, поклонов - сто.

книгохранилища (Предварителен списък), Pbg 32.4, 2008, p. 53-69; М. ЦиБРАНСКА-КОстовА, М. РАЙКОвА, Богомилите в игрковноюридическите текстове и паметниии, СЛ 39/40, 2008, р. 201-202; Д. НАЙДЕНОвА, О работе над каталогом славянских юридических рукописей из собраний болгарских библиотек, [in:] Современные проблемы археограбии. Сборник статей по материалам конферениии, проходившей в Библиотеке РАН 25-27 мая 2010 г., еd. И.М. БЕЛяЕВА, Санкт-Петербург 2011, р. 53-61; М. ЦиБРАнСКА-КостовА, Покайната книжнина на Българското средновековие IX-XVIII век. Езиково-текстологични и културологични аспекти, София 2011, р. 259-410; Д. НАЙДЕНОВА, Евреите в каноничноправните текстове (Ръкописи 3-I-63 и 3-I-68 от сбирката на Груич в Музея на Срғбската православна иғрква в Белград), [in:] Средновековният българин и „другите”. Сборник в чест на 60-годишнината на проб. дин Петър Ангелов, еd. А. Николов, Г.Н. Николов, София 2013, p. 319-329.

${ }_{35}$ А.А. Турилов, К истории тырновского „иарского” скриптория XIV в., СЛ 33/34, 2005, p. 319323; Е. БЕЛЯковА, О составе Хлудовского Номоканона (К истории сборника „Зинар”), СЛ 37/38, 2007, p. 114-131; ЕАDЕм, О задачах составления сводного каталога канонических памятников, [in:] Современные проблемы археограбии..., p. 48-52.

${ }^{36}$ НБИВ 101 доб.: скраку.

${ }^{37}$ НМРМ 1/20 доб.: Мєч'к 8 РИМШ 6, НБИВ 101 доб.: й нЕчк 8.

${ }^{38}$ РИМШ 6 доб.: и жав8.

${ }^{39}$ НБИВ 101 доб.: сороку. 
$\mathrm{Te}$, кто едят волка, лисицу ${ }^{40}$, пса, кошку, и ежа, крысу, куницу, белку и прочих других, которые нечисты, змею, черепаху ${ }^{41}$, и всяких зверей малых и великих, коня или осла, будь они из диких или пасомых, которых назвал нечистыми закон Божий: если окажется, что он это съел по своей воле и [собственному] желанию, пусть кается четыре года; а если не по своей воле и по принуждению съест, пусть кается один год, поклонов - пятнадцать.

Будущие исследования вероятно позволят идентифицировать более детально источники перечней нечистых животных в переводных и компилятивных славянских полемических произведениях против латинян. Здесь достаточно отметить, что перечисленные выше (и им подобные) тексты укоренили в сознании православных славян ряд негативных представлений о католиках. Отражения средневекового стереотипа, что западные люди едят мясо всяких нечистых животных и тварей, хорошо прослеживаются в болгарской литературе XIX-XX в. Так например, один из героев Л. Каравелова (1834-1879) восклицает: Да избавит нас Господь Бог от католиков и их гнусных деяний! Знаете ли вы, что венгры едят всякие нечистоты? Рассказывают, ито Людовик I ест и кошек, и мышей, и черепах ${ }^{42}$. Эти стереотипы очевидно перенеслись и на протестантов, поскольку другой герой Каравелова отмечает: Один греческий диакон мне рассказывал, что протестанты едят ящерии и что они причащаются вместе с иудеями ${ }^{43}$. Употребление лягушек в романе Д. Немирова (1882-1945) связывается с франками ${ }^{44}$, а в повести Й. Йовкова (1880-1937) - с немцами (щвабами) и итальянцами ${ }^{45}$.

Для нас, однако, особенно интересно поставить вопрос: как соотносились с действительностью средневековые книжные описания питательных привычек латинян.

Данные археологических раскопок на территории Болгарии дают нам возможность убедиться, что режим питания местного населения эпохи средневековья в целом не входил в разрез с нормами и ограничениями, которые стремилась поддерживать Православная Церковь. Основным источником мяса были крупный и мелкий рогатый скот, свиньи, туры (Bos primigenius), олени, косули, зубры, дикие кабаны, птицы; кости лисиц, волков, медведей, кошек, собак не обнаруживают следы обработки и пока нет оснований думать, что мясо этих животных служило пищей ${ }^{46}$.

\footnotetext{
${ }^{40}$ НМРМ 1/20 доб. медведя; РИМШ 6, НБИВ 101 доб.: или медведя.

${ }^{41}$ РИМШ 6 доб.: и лягушку.

42 Л. КАРАВЕЛОВ, Събрани съчинения в дванадесет тома, vol. II, Разкази и повести, еd. Д. ЛЕКов, София 1984, р. 289.

${ }^{43}$ Idem, op. cit., vol. V, Фейлетони, ed. Д. ЛЕков, София 1985, p. 317.

${ }^{44}$ Д. НЕмИРОв, Ангелогласният, София 1981, р. 74.

${ }^{45}$ Й. Йовков, Съчинения, vol. I, Разкази и повести, ed. С. Султанов, София 1981, p. 348.

${ }^{46}$ Р. Попов, Животински кости от историческо време, [in:] Мадара. Разкопки и проучвания, vol. I, София 1934, p. 221-239; С. ИвАнов, Храната от животински произход на обитателите от южната порта в Преслав, ИАИ 22, 1959, р. 209-219; С. ИвАНОВ, Животински костни остатьии от селището в местността Джеджови лозя при с. Попина, [in:] Ж. ВъЖАРовА, Славянски и славянобългарски селища в българските земи от края на VI-XI век, София 1965,
} 
Есть основания думать, что в некоторых раннесредневековых поселениях VIII-XI в. на территории Северо-Восточной Болгарии имело место более или менее частое употребление конины - факт, который свидетельствует о живучести старых номадских традиций болгар в период после официальной христианизации страны в 864 г. $^{47}$

В связи с этим уместно упомянуть, что византийские священники, отправленные в Болгарию патриархом Фотием, сделали попытку запретить употребление мяса некоторых животных, среди которых вероятно фигурировала и лошадь. Эти запреты нашли отражение в составленных в 866 г. ответах папы Николая на вопросы князя Бориса-Михаила, причем глава Римской церкви категорически отбросил введенные греками ограничения и позволил болгарам есть мясо всех животных (кроме мертвячины) ${ }^{48}$.

Интересно отметить, что в ходе раскопок крепости Перник на западе Болгарии, наряду с остатками большого количества мидий, устриц и улиток,

р. 207-225; В. ВАСИЛЕв, Животновъдство и лов в живота на населението от средновековното селище край Дуранкулак, [in:] Дуранкулак, vol. I, ed. Х. ТодоровА, София 1989, p. 225-245; $\mathrm{X}$. СтояновА, Средновековно селище до гр. Каспичан (по трасето на автомагистрала “Хемус"), ИИМШ 12, 2004, р. 94-95; Л. НИНОв, Сравнителни археозоологически проучвания от Плиска, [in:] Изследвания по бблгарска средновековна археология. Сборник в чест на проб. Рамо Рашев, еd. П. Георгиев, София 2007, р. 405-413; Н. Хрисимов, Храната в Първото българско изарство, [in:] Стандарти на всекидневието през Средновековието и Новото време, ed. К. Мутафова et al., Велико Търново 2012, р. 207-210, 217-218. Интересно отметить, что в ходе раскопок раннесредневекового славяноболгарского поселения VI-XI в. возле c. Гарван недалеко от Силистры (Северо-восточная Болгария) был обнаружен рог зубра, охарактеризованный археозоологами как наиболее позднее свидетельство об обитании этого вида в болгарских землях (Н. СПАСОв, Н. ИлиЕВ, Костни останки от зубър (Bison Bonasus L.) в средновековното селище край с. Гарван, Силистренски окрбг (нови изследвания), [in:] Ж. ВъЖАРовА, Средновековното селище с. Гарван, Силистренски окрбг VI-XI в., София 1986, р. 68). В действительности, есть основания думать, что зубр обитал северозападные болгарские земли даже в начале XIV в. Как указано в комментариях к последнему изданию анонимного Описания Восточной Европы 1308 г., упомянутые в оригинальном латинском тексте tigrides, которые водились в землях Видинского деспотства (охарактеризованном как imperium царство), суть не что иное, как зубры (Т. Живковић, В. ПЕтровић, А. УзЕЛАЦ, Anonymi Descriptio Europae Orientalis, ed., transl. et com. Д. Кунчер, Београд 2013, p. 171).

${ }^{47}$ С. ИвАнов, Домашните и дивите животни от Градището край с. Попина, [in:] Ж. ВъЖАРОвА, Славянобългарското селище село Попина, София 1965, р. 70: Към употребяваните за храна видове - говедо, ови, коза и свиня - трябва да добавим и коня, за който може със сигурност да се каже, че е бил също консумиран. Това виждаме от големия брой фрагменти от различни части на скелета, включително и черепа, значителна част от кочто показват ясни белези на удар с остьр предмет. Независимо от това фрагментирани конски кости, носещи сигурни белези на кухненски отпадъии, бяха намерени іп situ вътре в някои жилища върху подовата мазилка или до огнището. Лошадиные кости с следами кухонной обработки обнаружены также в ходе раскопок поселения XI-XII в. возле современного с. Ковачево, недалеко от г. Пазарджик в Южной Болгарии (Г. КОВАЧЕВ, Ц. МинКОВ, Животински костен материал от средновековното селище край с. Ковачево, Пазарджишки окрьг, [in:] Интердисииплинарни изследвания, vol. III/IV, София 1979, p. 85, табл. 1). Сf. также: Н. ХРисимов, ор. cit., p. 217.

${ }^{48}$ Nicolai I. papae epistolae, ed. E. Perels, [in:] MGH.E, vol. VI, Epistolae Karolini aevi IV, ed. IDEM, Berlin 1925, p. 583-585; Nicolai I papae ad consulta bulgarorum, ed. D. DečEv, [in:] FLHB, vol. II, ed. I. DujČEv et al., Serdicae 1960, p. 94-96. 
археологи обнаружили и панцирь черепахи, который носил следы термической обработки ${ }^{49}$. Учитывая этот факт, можно поставить вопрос не употребляли ли черепашье мясо и обитатели некоторых средневековых поселений в болгарских землях, где археологи нашли панцири черепах - с. Крум (возле г. Димитровград, Юго-Восточная Болгария) $)^{50}$, с. Дядово (возле г. Нова Загора, Юго-Восточная Болгария) ${ }^{51}$, с. Кладенци (возле г. Тервел, Северо-Восточная Болгария) $)^{52}$. При этом следует учитывать, что поселения возле Дядово и Крум возникли после окончательного присоединения Болгарского царства к Византии в 1018 г. - они основаны в XI в. и просуществовали до конца XII - начала XIII в. В этот период здесь квартировали византийские гарнизоны, в составе которых служили не только выходцы со всех концов империи, но и западные наемники - варяги, норманы, алеманны, англичане и другие кельты и латины. Наряду с этим, в болгарские земли проникли с севера и многочисленные группы печенегов и других степных кочевников ${ }^{53}$. Нельзя исключить вероятность, что именно с этими пришельцами связано появление черепашьих панцирей в перечисленных археологических объектах ${ }^{54}$.

Дошедшие до нас средневековые письменные источники не содержат конкретные свидетельства об употреблении черепах иностранцами из католического Запада. Весьма симптоматичны, однако, некоторые упоминания об этом в очерках более поздних путешественников по балканским владениям Османской империи.

\footnotetext{
${ }_{49}$ Й. ЧАнговА, Храна на населението, [in:] ЕАDEм, Перник, vol. III, Крепостта Перник VIII$X I V$ в., София 1992, p. 11, 18.

${ }^{50}$ Е. ЕвтимовА, Средновековно селище и некропол в землището на с. Крум, Димитровградско, [in:] Археологически открития и разкопки през 2007 г., София 2008, p. 665.

${ }^{51}$ B. Borisov, Djadovo, vol. I, Mediaeval settlement and necropolis (11th-12th century), Tokyo 1989, p. 315; IDEM, Икономиката на средновековното селище върху селищната могила до с. Дядово, Бургаско, ИМЮБ 14, 1991, р. 74.

52 Л. Нинов, Животинска и ловна дейност на обитателите на крепостта, [in:] В. Йотов, Г. АТАнасов, Скала. Крепост от X-XI век до с. Кладенци, Тервелско, София 1998, р. 330.

${ }^{53}$ Об этнических и демографических процессах на территории завоеванного Византией Болгарского царства в XI-XII в.: И. БожилОв, В. ГюзЕлЕв, История на средновековна България VII$X I V$ век, София 1999, p. 383-387. Следует также отметить печати византийских сановников западного происхождения, обнаруженные в болгарских землях: И. ЙордАнов, Печати на византийски сановници от западен произход (XI-XII в.), намерени в днешна България, НСЕ 1, 2004, 181-200; I. Jordanov, Corpus of Byzantine Seals from Bulgaria, vol. II, Byzantine Seals with Family Names, Sofia 2006, p. 115-116 (№ 150), 252-254 (№ 398), 312-315 (№ 529-532), 354-357 (№ 596-597), 395-397 (№ 696), 416-419 (№ 730-731), 424-425 (№ 737-737А).

${ }^{54}$ Вопрос о следах употребления черепах степными номадами нуждается в дополнительном изучении. Здесь отметим, что в позднеаварском могильнике Топонар VIII - начала IX в., расположенном в 9 км. к северо-востоку от г. Капошвар (Юго-западная Венгрия), в трех могилах воинов было найдено всего пять панцирей черепах, причем в двух из всех трех случаев погребения сопровождались конскими захоронениями; подобное погребение с двумя черепахами в могиле воина было раскопано в могильнике VI - VIII в. Бадьог (Е. СимоновА, Новые могильники позднеаварского времени в области Шомодь, САрх 1976, № 1, p. 262). Стоит также напомнить, что гепиды, которые в конце 60-х годов VI в. оказались под верховенством аваров, имели обычай собирать и есть черепах (I. BónA, The dawn of the Dark Ages: the Gepids and the Lombards in the Carpathian Basin, Budapest 1976, p. 45).
} 
Так например, в 1585 г. Франсуа де Пави (1563-1611) отмечает, что в водах Черного моря у берегов современной Болгарии водились морские черепахи необыкновенно больших размеров; и хотя турки не имели привычку есть их мясо, экипаж французского корабля часто ловил и готовил этих черепах ${ }^{55}$.

Прославленный своими путешествиями дипломат Франсуа Пуквиль (1770-1838) неоднократно регистрирует в своих путевых записках о Балканах наличие здесь многочисленных колоний черепах и объясняет это отвращением, которое питают к ним греки и турки ${ }^{56}$.

Во время своего пребывания в 1836 г. в г. Качаник (на юге Косово) французский географ и геолог Ами Буе (1794-1881) был впечатлен индифферентностью локального населения к черепахам:

Нас удивило также количество черепах и их яиц. Местные жители их не едят, не собирают, и некоторые из них еще вспоминали с удивлением, как в 1806 г. г-н Гюго Пуквиль приготовил несколько черепах. В приморской Албании их собирают и вывозят. ${ }^{57}$

Учитывая изложенное, нельзя удивляться, что еще со времен распространения католической пропаганды в болгарских землях в XVII в. вплоть до наших дней болгарские католики (преимущественно местные потомки павликиан), большинство которых обитает в регионе Пловдива (Южная Болгария), готовят и употребляют черепах (наряду с рыбой) даже во время поста ${ }^{58}$. Это было хорошо известно православным болгарам, которые обзывали своих соотечественников католического вероисповедания пренебрежительным прозвищем желвари (черепахоеды) ${ }^{59}$. Более общее представление о привычке болгарских католиков (большинство которых являлись

\footnotetext{
${ }_{55}^{5}$ Франсоа дьо Пави, сеньор дьо Фуркево, еd. Б. ЦветКОВА, сот. П. КОЛЕДАРОВ, Б. ЦвЕТКОВА, [in:] Френски пгтеписи за Балканите, vol. I, XV-XVIII в., ed. Б. ЦветковА, София 1975, p. 180 (болгарский перевод неопубликованной рукописи, которая хранится в Национальной библиотеке в Париже).

${ }^{56}$ F. POUQueville, Voyage de la Grèce, vol. V, Paris 1827, p. 291.

${ }^{57}$ A. BouÉ, Recueil d'itinéraires dans la Turquie d'Europe, vol. I, Vienne 1854, p. 207-208; Д-p Амu Буe $/ 1836,1837,1838 /$, intr. К. Възвъ3ОвА, trans. Б. ЦВЕТКОВА, М. КИСЕЛИНЧЕВА, К. ВъЗВЪЗОВА, com. П. КОЛЕДАРОВ, Б. ЦвЕТКОВА, К. ВъзвъзОвА, [in:] Френски пбтеписи за Балканите, vol. II, XIX век, еd. Б. ЦвеТКОВА, София 1981, р. 334.

58 Л. РАдЕвА, Храна и хранене, [in:] Пловдивски край. Етнографски и езикови проучвания, ред. Г. Михайлова, София 1986, р. 166, 177; М. Йовков, Павликяни и павликянски селища в бблгарските земи XV-XVIII в., София 1991, р. 73; А. Янков, Календарни празници и обичаи на българите католици (края на ХІХ - средата на ХХ век), София 2003, р. 103. К перечисленным публикациям можно добавить и недавнее свидетельство археологии. Весной 2013 г., в ходе спасательных раскопок в г. Пловдив на ул. „Граф Игнатиев” № 22, археологи под руководством Е. Божиновой нашли в слоях конца XIX - начала XX в. (когда в этой зоне города жили болгарские католики) целое скопление черепашьих панцирей. Эта находка пока не имеет параллелей в доступных материалах прежних раскопок в тех кварталах города, где обитали православные болгары, греки и турки.

${ }_{59}$ М. МАДЖАРОВ, Мемоари, София 1968, р. 760; А. ХРИСТОФОРОв, Откровения. Поля, гори и хора, София 1970, p. 30-31; М. МлАденов, Диалектология, балканистика, етнолингвистика, София 2008, p. 462.
} 
потомками еретиков-павликиан) есть мясо разных нечистых животных здесь можно проиллюстрировать высказыванием пожилой женщины из с. Горно Павликени (в окрестностях г. Ловеч, Северная Болгария), записанном Л. Милетичем в конце XIX в.: павликиане ели сусликов, ящзерии; мы не как они - мы чистые люди ${ }^{60}$.

В заключение к этому далеко не полному обзору можно отметить, что изложенные примеры перехода на бытовой уровень религиозного диалога и полемики разных эпох нельзя рассматривать как изолированное или случайное явление. Отмеченная тенденция была обусловлена стремлением православных обществ на Балканах и в Восточной Европе укрепить разнообразными средствами свою этно-религиозную идентичность в контексте острого политического и конфессионального противопоставления с римокатолическим миром Западной Европы. Как мы постарались показать, эта проблематика подлежит дальнейшему изучению не только в плане выявления новых списков и версий средневековых полемических произведений; важной научной задачей является также полноценное привлечение данных археологии, этнологии и фольклористики, что позволило бы выявить источники, пути формирования и трансформации основных характеристик идентичности славянских православных обществ эпохи Средневековья и Нового времени.

\begin{abstract}
Ritual deviations and bad habits of the 'Latin heretics' in Byzantine and Slavic polemical literature of the Middle Ages. The paper discusses the differences between Eastern and Western Christians during the Middle Ages through the prism of the lists of ritual deviations and bad habits of the 'Latin heretics', which were circulated in Byzantium in the second half of the 12th century (following the Great Schism of 1054). The translations and revisions of these lists remained popular among the Orthodox Christians in the Balkans and Eastern Europe up until the end of the 17th century.

Special attention has been given to the reception among the Slavs of two Byzantine accusations levelled on the westerners - (1) that their priests shave; (2) that they eat various 'unclean' animals and creatures.

The examples of the peculiar mundanity of the religious dialogue and polemics analysed in the paper suggest that this was a trend resulting from the ambition of the Orthodox societies in the Balkans and Eastern Europe to strengthen through various means their ethnic and religious identity in the context of the fierce political and confessional confrontation with the Catholic world of Western Europe. Also highlighted is the need for the research of medieval polemical texts to embrace the archaeological, ethnological and folkloristic evidence, which would allow us to clarify the sources and trends in the development and transformation of the key features of the identity of Slavic Orthodox societies during the Middle Ages and Modernity.
\end{abstract}

$\overline{60}$ Л. МилЕтич, Нашите павликяни, СНУНК 19, 1903, p. 49. 
Ключевые слова: православная антилатинская полемика, средневековые полемические тексты, православная идентичность, православно-католические отношения, религиозный диалог

Keywords: Orthodox anti-Latin polemics, medieval polemical texts, Orthodox identity, OrthodoxCatholic relations, religious dialogue

Angel Nikolov Chair of the Bulgarian History St. Kliment of Ochrid Sofia Univeristy 15 Tsar Osvoboditel blvd. 1504 Sofia, Bulgaria anikolov2003@yahoo.com

Kamen Stanev Cyrillo-Methodian Research Centre of the Bulgarian Academy of Sciences 13 Moskovska Street 1000 Sofia, Bulgaria kamen_stratiot@abv.bg 